\title{
Effects of metal ions on growth, $\beta$-oxidation system, and thioesterase activity of Lactococcus lactis
}

\author{
Liang $\mathrm{Li}^{*} \dagger$ and Ying $\mathrm{Ma}^{* 1}$ \\ *School of Food Science and Engineering, Harbin Institute of Technology, 202 Haihe Road, Harbin, Heilongjiang 150090, China \\ †College of Food Science, Northeast Agricultural University, 59 Gongbin Road, Harbin, Heilongjiang 150030, China
}

\begin{abstract}
The effects of divalent metal ions $\left(\mathrm{Ca}^{2+}, \mathrm{Mg}^{2+}, \mathrm{Fe}^{2+}\right.$, and $\mathrm{Cu}^{2+}$ ) on the growth, $\beta$-oxidation system, and thioesterase activity of Lactococcus lactis were investigated. Different metal ions significantly influenced the growth of L. lactis: $\mathrm{Ca}^{2+}$ and $\mathrm{Fe}^{2+}$ accelerated growth, whereas $\mathrm{Cu}^{2+}$ inhibited growth. Furthermore, $\mathrm{Mg}^{2+}$ inhibited growth of L. lactis at a low concentration but stimulated growth of L. lactis at a high concentration. The divalent metal ions had significant effects on activity of the 4 key enzymes of the $\beta$-oxidation system (acyl-CoA dehydrogenase, enoyl-CoA hydratase, L-3-hydroxyacyl-CoA dehydrogenase, and thiolase) and thioesterase of L lactis. The activity of acyl-CoA dehydrogenases increased markedly in the presence of $\mathrm{Ca}^{2+}$ and $\mathrm{Mg}^{2+}$, whereas it decreased with $1 \mathrm{mmol} / \mathrm{L}$ $\mathrm{Fe}^{2+}$ or $12 \mathrm{mmol} / \mathrm{L} \mathrm{Mg}^{2+}$. All the metal ions could induce activity of enoyl-CoA hydratase. In addition, $12 \mathrm{mmol} / \mathrm{L} \mathrm{Mg}^{2+}$ significantly stimulated activity of L-3-hydroxyacyl-CoA dehydrogenase, and all metal ions could induce activity of thiolase, although thiolase activity decreased significantly when $0.05 \mathrm{mmol} / \mathrm{L}$ $\mathrm{Cu}^{2+}$ was added into M17 broth. Inhibition of thioesterase activity by all 4 metal ions could be reversed by $2 \mathrm{mmol} / \mathrm{L} \mathrm{Ca}^{2+}$. These results help us understand the effect of metal ions on the $\beta$-oxidation system and thioesterase activity of Lactococcus lactis.
\end{abstract}

Key words: metal ion, $\beta$-oxidation system, thioesterase, Lactococcus lactis

\section{INTRODUCTION}

Lactococcus lactis strains are the predominant lactic acid bacteria components of commercial starter cultures used by the dairy industry for the manufacture and ripening of cheese and fermented milk (Alegría et al., 2010). Starter L. lactis have an important effect on flavor precursor development, especially in the genera-

Received February 13, 2014.

Accepted May 20, 2014.

${ }^{1}$ Corresponding author: maying@hit.edu.cn tion of methyl ketones, which is related to incomplete $\beta$-oxidation in cheese and fermented milk (Hannon et al., 2007; Li and Ma, 2013). The $\beta$-oxidation pathway is a cycle of 4 sequential reactions in which the FA substrate is shortened by 2 carbons with each cycle (Kurtz et al., 1998). Fatty acyl-CoA is first oxidized to enoyl-CoA, enoyl-CoA is then hydrated to hydroxyacyl-CoA, which is in turn oxidized to ketoacyl-CoA (Maggio-Hall et al., 2008 ), but $\beta$-ketoacyl-CoA may not be metabolized to acetyl-CoA units via $\beta$-oxidation. $\beta$-Ketoacyl-CoA can be deacylated into $\beta$-ketoacids under the action of the thioesterases, which can catalyze the hydrolysis of acylCoA to FFA and CoA (Hunt and Alexson, 2002), and the ketoacid is then decarboxylated to methyl ketone (Engelvin et al., 2000). Incomplete $\beta$-oxidation is associated with 4 key enzymes in the $\beta$-oxidation system (acyl-CoA dehydrogenases, enoyl-CoA hydratase, L3-hydroxyacyl-CoA dehydrogenase, and thiolase) and thioesterase.

In addition, the ionic environment may interfere with bacterial cell walls, especially in gram-positive bacteria, and modify electron flow in a substrate or enzyme, thus effectively controlling an enzyme-catalyzed reaction (Ellwood and Tempest, 1972; Glusker et al., 1999). From the literature, many researchers have studied the effects of metal ions on the growth of lactic acid bacteria and enzymes in metabolic processes; however, little information has been reported on the effect of divalent metal ions on the $\beta$-oxidation system and thioesterase activity of L. lactis (Eades and Womack, 1953; Boyaval, 1989; Imbert and Blondeau, 1998).

The objective of this study was to investigate the effects of $\mathrm{Ca}^{2+}, \mathrm{Mg}^{2+}, \mathrm{Fe}^{2+}$, and $\mathrm{Cu}^{2+}$ on the growth, $\beta$-oxidation system, and thioesterase activity of $L$. lactis. These results will provide a new way of regulating FA metabolism and, in turn, methyl ketone synthesis related to FA metabolism.

\section{MATERIALS AND METHODS}

\section{Chemicals}

CoA, crotonoyl coenzyme A, acetoacetyl coenzyme $\mathrm{A}$ and palmitoyl-CoA were purchased from Sigma- 
Aldrich Co. Ltd. (Shanghai, China). 5,5'-Dithiobis-(2nitrobenzoicacid) (DNTB), HEPES, NADH, phenylmethanesulfonyl fluoride (PMSF), BSA, phenazine metosulfate, and EDTA were purchased from Aladdin Chemistry Co. Ltd. (Shanghai, China). The Enhanced BCA Protein Assay kit was purchased from Beyotime Institute of Biotechnology (Jiangsu, China).

\section{Microorganism}

Lactococcus lactis ssp. lactis was isolated from a traditional dairy product in China, identified by morphological and genetic methods, and grown in M17 broth medium (Hope Bio-Technology Co., Qingdao, China) at $37^{\circ} \mathrm{C}$ (Terzaghi and Sandine, 1975). The strain was maintained at $-20^{\circ} \mathrm{C}$. The cultures were activated at least 3 times before use.

Ferric sulfate, calcium chloride, copper sulfate, and magnesium sulfate were used as metal ion supplements in M17 broth for growth tests. Cell density was measured by using a spectrophotometer (TU-1800 Pgeneral Instrument Co. Ltd., Beijing, China) at $600 \mathrm{~nm}$ after $18 \mathrm{~h}$ of growth (Papagianni et al., 2007). All enzyme activities were measured after $18 \mathrm{~h}$ of growth of L. lactis ssp .lactis.

\section{Preparation of Cell-Free Extracts}

For preparation of the cell-free extracts, cells were grown in $1 \mathrm{~L}$ of medium for $18 \mathrm{~h}$. Cell-free extracts were prepared essentially as described by Engelvin et al. (2000) with modifications. Cells were harvested at 5,000 $\times g$ for 10 min at $4^{\circ} \mathrm{C}$, washed with $\mathrm{K}_{2} \mathrm{HPO}_{4}-\mathrm{KH}_{2} \mathrm{PO}_{4}$ $(100 \mathrm{mmol} / \mathrm{L}, \mathrm{pH} 7.5)$, and sonicated in HEPES buffer $(20 \mathrm{mmol} / \mathrm{L}, \mathrm{pH} 7.5)$ containing $1 \mathrm{mmol} / \mathrm{L}$ EDTA and $1 \mathrm{mmol} / \mathrm{L}$ PMSF using an ultrasonic homogenizer (JY92-II, Ningbo Scientz Biotechnology Co. Ltd., Ningbo, China), with 30 cycles of $10 \mathrm{~s}$ on and $10 \mathrm{~s}$ off at $300 \mathrm{~W}$. Unbroken bacteria were removed by centrifugation $\left(5,000 \times g, 10 \mathrm{~min}, 4^{\circ} \mathrm{C}\right)$. The supernatant fraction was designated the crude cell-free extract $(\mathbf{C F E})$ and was used immediately or stored at $-80^{\circ} \mathrm{C}$. The content of protein in the CFE was determined by using the Enhanced BCA Protein Assay Kit.

\section{SDS-PAGE Analysis}

Sodium dodecyl sulfate-PAGE was performed in a Mini-Protean 3 Cell apparatus (Bio-Rad Laboratories, Hercules, CA) according to the modified procedure of Laemmli (1970), which used $12 \%$ separating gels $(0.375 \mathrm{~mol} / \mathrm{L}$ Tris-HCl, $\mathrm{pH} 8.8$, and $0.1 \%$ SDS $)$ and $4 \%$ stacking gels $(0.125 \mathrm{~mol} / \mathrm{L}$ Tris- $\mathrm{HCl}, \mathrm{pH} 6.8$, and $0.1 \%$ SDS), respectively, and a buffer system contain- ing $0.025 \mathrm{~mol} / \mathrm{L}$ Tris-HCl, $0.192 \mathrm{~mol} / \mathrm{L}$ Gly, and $0.1 \%$ SDS, pH 8.3. Samples were mixed with reducing sample buffer (10\% SDS, $2.5 \% \beta$-mercaptoethanol) to give a concentration of $2 \mathrm{mg} / \mathrm{mL}$ and were heated at $95^{\circ} \mathrm{C}$ for $5 \mathrm{~min}$. Ten microliters of each sample was loaded per lane. Electrophoresis was run at $10 \mathrm{~mA}$ before the sample was into the separating gel, , and run at $20 \mathrm{~mA}$ after the sample was into the separating gel. The gel was stained with a mixed solution of $0.1 \%$ Coomassie Brilliant Blue R-250 in 40\% methanol and $10 \%$ acetic acid, and destained with a solution of $40 \%$ methanol and $10 \%$ acetic acid. Protein molecular weights were estimated using a protein molecular weight marker (SM0431, Fermentas/Thermo Scientific, Waltham, MA), including $\beta$-galactosidase (116 kDa), BSA (66.2 $\mathrm{kDa})$, ovalbumin $(45.0 \mathrm{kDa})$, lactate dehydrogenase (35.0 kDa), REase Bsp981 (25.0 kDa), $\beta$-LG (18.4 kDa), and lysozyme $(14.4 \mathrm{kDa})$. The densitometric analyses of the bands were done using the Biorad ChemiDoc XR system and software (Bio-Rad Laboratories).

\section{Acyl-CoA Dehydrogenase Activity}

Acyl-CoA dehydrogenase (EC 1.3.99.3) was determined according to the procedure of Baltazar et al. (1999) and Feron et al. (2005). Total activity was determined in $1 \mathrm{~mL}$ of HEPES/KOH buffer $(50 \mathrm{mmol} / \mathrm{L}$, $\mathrm{pH} 8.0$ ), and the reduction of $100 \mu \mathrm{mol}$ of 2,6-dichlorophenolindophenol (DCPIP) was monitored at $600 \mathrm{~nm}$ in the presence of $50 \mu \mathrm{mol}$ of phenazine metosulfate, 72 nmol of acyl CoA, and $200 \mu \mathrm{g}$ of CFE. An absorption coefficient of $21,500 M^{-1} \cdot \mathrm{cm}^{-1}$ was used for DCPIP at $\mathrm{pH}$ 8.0.

\section{Enoyl-CoA Hydratase Activity}

Enoyl-CoA hydratase (crotonase; EC 4.2.1.17) was assayed by following the decrease in absorbance at 263 $\mathrm{nm}$ due to the hydration of the $\Delta-2,3$ double bond of the substrate (Binstock and Schulz, 1981). The assay mixture contained $0.2 \mathrm{~mol} / \mathrm{L}$ potassium phosphate, $\mathrm{pH}$ 8 , BSA $(0.2 \mathrm{mg} / \mathrm{mL})$, and $30 \mu \mathrm{mol} / \mathrm{L}$ crotonyl-CoA. The reaction was started by addition of the enzyme. An extinction coefficient $(\varepsilon)$ of $6,700 M^{-1} \cdot \mathrm{cm}^{-1}$ was used to calculate rates

\section{L-3-Hydroxyacyl-CoA Dehydrogenase Activity}

L-3-Hydroxyacyl-CoA dehydrogenase (EC 1.1.1.35) was routinely assayed by measuring the decrease in absorbance at $340 \mathrm{~nm}$ due to the dehydrogenation of NADH (Binstock and Schulz, 1981). The assay mixture contained $0.1 \mathrm{~mol} / \mathrm{L}$ potassium phosphate, $\mathrm{pH} 7$, BSA $(0.2 \mathrm{mg} / \mathrm{mL}), 0.1 \mathrm{mmol} / \mathrm{L} \mathrm{NADH}$, and $30 \mu \mathrm{mol} / \mathrm{L}$ ace- 
toacetyl-CoA. The assay was begun by addition of the enzyme. An extinction coefficient $(\varepsilon)$ of $6,220 M^{-1} \cdot \mathrm{cm}^{-1}$ was used to calculate rates.

\section{Thiolase Activity}

3-Ketoacyl-CoA thiolase (EC 2.3.1.16) was assayed by measuring the decrease in absorbance at $303 \mathrm{~nm}$ due to the disappearance of the $\mathrm{Mg}^{2+}$ enolate complex of the substrate (Binstock and Schulz, 1981). The assay mixture contained $0.1 \mathrm{~mol} / \mathrm{L}$ HEPES, $\mathrm{pH} 8.1,25$ $\mathrm{mmol} / \mathrm{L} \mathrm{MgCl}_{2}$, BSA $(0.2 \mathrm{mg} / \mathrm{mL}), 2 \mathrm{mmol} / \mathrm{L}$ mercaptoethanol, $5 \%$ (vol/vol) glycerol, $0.1 \mathrm{mmol} / \mathrm{L}$ coenzyme $\mathrm{A}$, and $30 \mu \mathrm{mol} / \mathrm{L}$ acetoacetyl-CoA. The reaction was begun by addition of the enzyme. Extinction coefficient for acetoacetyl-CoA in HEPES buffer was 12,000 $M^{-1} \cdot \mathrm{cm}^{-1}$.

\section{Thioesterase Activity}

Thioesterase activity was determined according to the procedure of Engelvin et al. (2000). Thioesterase activity was measured by the release of CoASH, which was assayed continuously by its reaction with DTNB. The assay contained, in a final volume of 1 $\mathrm{mL}, \mathrm{K}_{2} \mathrm{HPO}_{4}-\mathrm{KH}_{2} \mathrm{PO}_{4}(300 \mathrm{mmol} / \mathrm{L}, \mathrm{pH} 8.0), 250 \mathrm{nmol}$ of DTNB, $72 \mathrm{nmol}$ of palmitoyl-CoA, and $280 \mu \mathrm{g}$ of $\mathrm{CFE}$ protein. Activity was measured by following the increase in absorbance at $412 \mathrm{~nm}$ against a control without substrates $\left[\varepsilon_{\text {DTNB }}(412)=13,600 \mathrm{M}^{-1} \cdot \mathrm{cm}^{-1}\right]$. Activity was expressed as nanomoles of palmitoyl-CoA deacylated per milligram of protein per minute.

\section{Statistical Analysis}

All statistical analyses, including one-way ANOVA and the Duncan multiple-range test, were performed by using SPSS 17.0 software (SPSS Inc., Chicago, IL). All experiments were performed at least in triplicate, and mean values \pm standard deviations were used for analyses.

\section{RESULTS AND DISCUSSION}

\section{Whole-Cell Protein Analysis by SDS-PAGE}

The whole-cell protein profiles showed that the molecular weight of major subunits ranged from 25 to 50 $\mathrm{kDa}$ (Figure 1). These results were in accordance with previous descriptions: acyl-CoA dehydrogenase had a subunit with mass of approximately $43 \mathrm{kDa}$ (Zeng et al., 2006; Maher et al., 2010); enoyl-CoA hydratase is composed of 6 identical subunits of $26 \mathrm{kDa}$ each; 3-hydroxyacyl-CoA dehydrogenase consists of 2 identi- cal subunits of $32 \mathrm{kDa}$ each (Yokota and Hashimoto, 1984); and thiolase has a subunit of $41 \mathrm{kDa}$ (Mannaerts et al., 2000). Thioesterase showed a band at $38 \mathrm{kDa}$ consistent with the $33 \mathrm{kDa}$ component that is a degradation product generated during purification (Hellyer et al., 1992). Based on the previous studies and our results, we predict that L. lactis has these active subunits of the 5 enzymes.

\section{Effect of Metal lons on the Growth of L. lactis}

The effects of different concentrations of metal ions on the growth of L. lactis are shown in Figure 2. The addition of $\mathrm{Mg}^{2+}$ to M17 could stimulate (at $8-20 \mathrm{mmol} / \mathrm{L}$ ) the growth of L. lactis or inhibit it (at $4 \mathrm{mmol} / \mathrm{L}$; Figure 2A). This result was similar to that found in previous research (Wright and Klaenhammer, 1983), which reported that supplementation of Chelexexchanged basal broth with magnesium (1-30 mmol/L) resulted in a proportional growth response in Lactobacillus bulgaricus 1243 . In contrast, the growth of $L$. lactis ssp. lactis CNRZ 1076 was unchanged when $\mathrm{Mg}^{2+}$ and $\mathrm{Mn}^{2+}$ were added to reconstituted skim milk (Bellengier et al., 1997). Growth rates of L. lactis ssp. lactis NCDO 2118 were reported to be affected when $\mathrm{Mg}^{2+}$ concentrations $<15 \mu \mathrm{mol} / \mathrm{L}$ (Loubiere et al., 1997), and $\mathrm{Mg}^{2+}$ resulted in a significant increase in viable count of Lactococcus rhamnosus FTDC 8313 when cultivated in reconstituted skimmed milk with $\mathrm{Mg}$ at 0 to $2 \mathrm{mg} /$ mL (Lew et al., 2013).

As shown in Figure 2B, we found no significant change in growth rate with $\mathrm{Ca}^{2+}$ concentrations $<12$ $\mathrm{mmol} / \mathrm{L}(P>0.05)$ but growth decreased dramatically when $\mathrm{Ca}^{2+}$ concentration increased from 12 to 20 $\mathrm{mmol} / \mathrm{L}$. Our results differ from other works. Eades and Womack (1953) claimed that calcium when added to medium at 0.025 to $12.5 \mathrm{mmol} / \mathrm{L}$ stimulated the early growth of Lactobacillus casei ATCC 7469. Wright and Klaenhammer (1983) noted that Lactobacillus bulgaricus 1243 had a proportional growth response in Chelex-exchanged basal broth supplementation with calcium at 0.001 to $1 \mathrm{mmol} / \mathrm{L}$.

As shown in Figure $2 \mathrm{C}, \mathrm{Fe}^{2+}$ inhibited the growth of L. lactis. Data presented by Efstathiou and McKay (1977) showed that lactose-metabolizing strains of Streptococcus lactis were more sensitive to copper compared with the lactose-negative derivatives, and Mrvčić et al. (2013) showed that added $\mathrm{Cu}^{2+}$ inhibited the growth of lactic acid bacteria. In the current study, copper ions stimulated the growth of L. lactis (Figure 2D).

In this study, we examined the influence of some divalent cations on the growth of L lactis. The relationships between the growth of $L$. lactis and metal ions are variable: sometimes they have no effects (Bellengier 


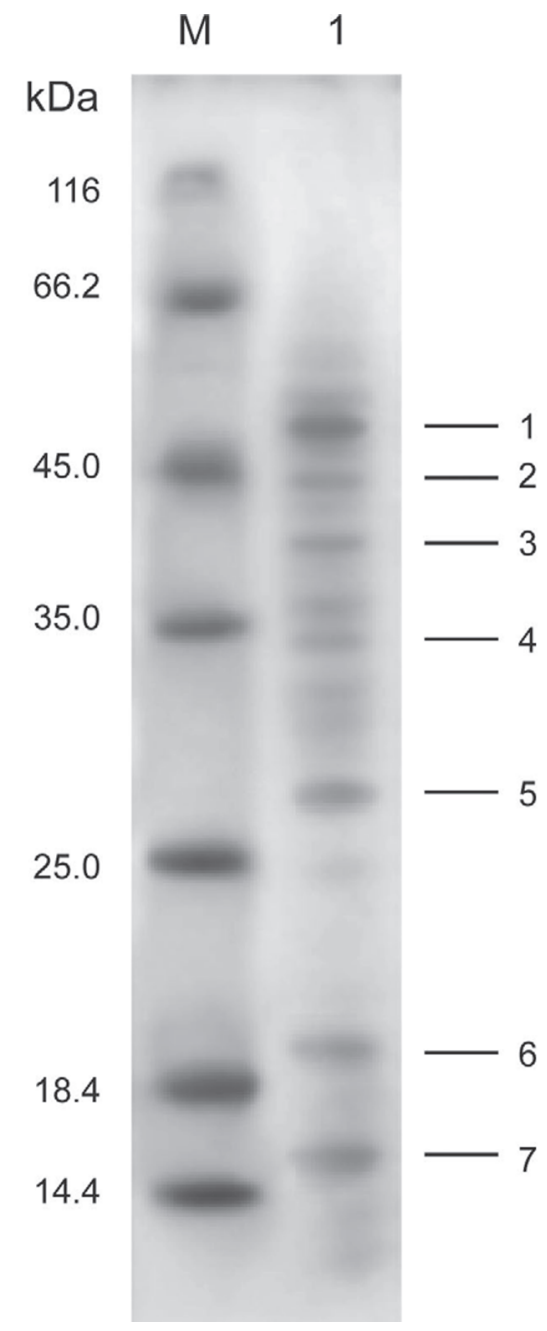

Figure 1. Whole-cell protein profiles of Lactococcus lactis ssp. lactis by using SDS-PAGE. Lane $\mathrm{M}=$ marker; lane $1=$ whole-cell protein; numbers 1 through 7 in lane 1 indicate the major subunits of whole-cell protein.

et al., 1997) but sometimes they have inhibitory effects $\left(\mathrm{Fe}^{2+}, \mathrm{Ca}^{2+}\right)$ or positive effects $\left(\mathrm{Mg}^{2+}, \mathrm{Cu}^{2+}\right.$; Figure 2$)$. Our results indicated that metal ions had an important influence on the growth of L. lactis.

Both $\mathrm{Mg}^{2+}$ and $\mathrm{Cu}^{2+}$ had positive effects on the growth of L lactis. The essential requirement for $\mathrm{Mg}^{2+}$ in growth is explained by the fact that it acts as an activator of different metabolic reactions, cell division, and stabilization of DNA and RNA (Boyaval, 1989). Although $\mathrm{Cu}^{2+}$ can be highly toxic to microorganisms at high concentrations, the presence of copper may provide selection pressure that causes the microbial population to adapt to environmental conditions (Trevors and Cotter, 1990); L. lactis (in this study) and Lactobacillus delbrueckii (Rodríguez and Alatossava, 2008) are most resistant to copper compared with other lactobacilli.
Both $\mathrm{Fe}^{2+}$ and $\mathrm{Ca}^{2+}$ had inhibitory effects on the growth of L. lactis (Figure 2). However, researchers have rarely studied the effects of iron on the growth of lactic acid bacteria, because lactic acid bacteria are thought to be an exception among living organisms in that they have no requirement for iron (Bruyneel et al., 1989). However, genome sequences of Lactobacillus sakei $23 \mathrm{~K}$ as well as L. lactis MG1363 reveal that lactic acid bacteria have genes that code for proteins involved in iron transport (Mrvčić et al., 2012). Imbert and Blondeau (1998) confirmed that iron did not induce any significant growth in lactobacilli. A few reports have shown that $\mathrm{Fe}^{2+}$ inhibits growth of Lactobacillus johnsonii (Elli et al., 2000). Dunning et al. (1998) described the damage (including lethal damage) induced by $\mathrm{Fe}^{2+}$ to oral streptococci but not to Lactobacillus casei ATCC 4646. Therefore, the inhibitory effects of $\mathrm{Fe}^{2+}$ on lactic acid bacteria must be further studied. From our results, we can conclude that variations in metal ion sensitivity and resistance may reflect variability in species, strains, media, cation contents, and different culture conditions.

\section{Influence of $\mathrm{Mg}^{2+}$ on Enzyme Activity}

Activities of 5 enzymes of incomplete $\beta$-oxidation were detected in the extracts of L. lactis grown in M17 broth with different concentrations of $\mathrm{Mg}^{2+}$ (Table 1). Levels of acyl-CoA dehydrogenase activity were enhanced 1.8-fold when the concentration of $\mathrm{Mg}^{2+}$ in M17 broth was $16 \mathrm{mmol} / \mathrm{L}$ and were reduced 3-fold when the concentration of $\mathrm{Mg}^{2+}$ was $12 \mathrm{mmol} / \mathrm{L}$. Levels of enoyl-CoA hydratase activity and L-3-hydroxyacylCoA dehydrogenase activity exhibited different degrees of increase. Thiolase activity was increased 23-fold with $8 \mathrm{mmol} / \mathrm{L} \mathrm{Mg}^{2+}$. This result was similar to that of other thiolases: the activity of rat mitochondrial 3-ketoacyl-CoA thiolase was stimulated by $\mathrm{Mg}^{2+}$ in Tris-HCl buffer (Zeng and Li, 2004), but the activity of acetoacetyl-CoA thiolase from Halobacterium strain ZP-6 was inhibited by $20 \mathrm{mmol} / \mathrm{L} \mathrm{Mg}^{2+}$ (Liu et al., 2002). Activity of thioesterase is decreased by different concentrations of $\mathrm{Mg}^{2+}$. The activity of the enzyme located in pig heart muscle mitochondria was not stimulated by $\mathrm{Mg}^{2+}$ (Lee and Schulz, 1979), but $2.5 \mathrm{mmol} / \mathrm{L}$ $\mathrm{Mg}^{2+}$ had marked stimulatory effects on activities of the short- and medium-chain thioesterases in brown adipose tissue mitochondria (Alexson and Nedergaard, 1988). Long-chain fatty acyl-CoA thioesterase activity was stimulated by $0.5 \mathrm{mmol} / \mathrm{L} \mathrm{Mg}^{2+}$ and inhibited at high concentrations (Berge and Døssland, 1979). From these results, we can conclude that $\mathrm{Mg}^{2+}$ stimulated activity of acyl-CoA dehydrogenase, enoyl-CoA hydra- 

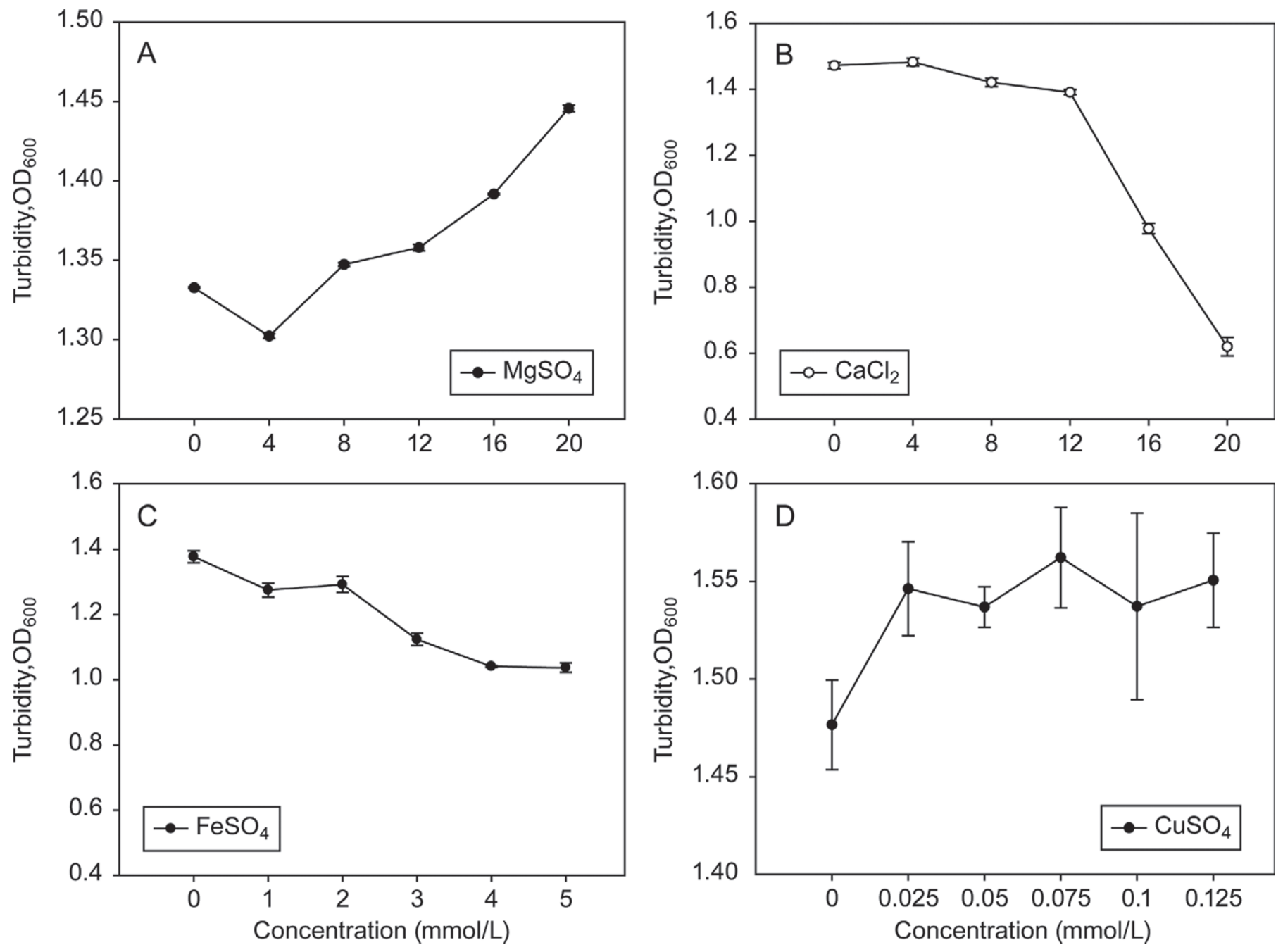

Figure 2. Effect of concentration of metal ions on the growth of Lactococcus lactis. OD = optical density.

tase, L-3-hydroxyacyl-CoA dehydrogenase, and thiolase but did not stimulate activity of thioesterase.

\section{Influence of $\mathrm{Ca}^{2+}$ on Enzyme Activity}

Calcium ions stimulated activity of acyl-CoA dehydrogenase, enoyl-CoA hydratase, and thiolase when the concentration was $<10 \mathrm{mmol} / \mathrm{L}$. However, for L-3-hydroxyacyl-CoA dehydrogenase and thioesterase, the role of stimulating or inhibiting enzyme activities depended on calcium concentration (Table 2). Thioesterase activity was stimulated by $\mathrm{Ca}^{2+}$ only at $2 \mathrm{mmol} / \mathrm{L}$ in this study, which differs from the results of Lee and Schulz (1979). The finding of the influence of $\mathrm{Ca}^{2+}$ on enzyme

Table 1. Influence of $\mathrm{Mg}^{2+}$ concentration on enzyme activity ( $\mathrm{nmol} / \mathrm{min}$ per $\mathrm{mg}$ of protein)

\begin{tabular}{|c|c|c|c|c|c|}
\hline $\begin{array}{l}\mathrm{Mg}^{2+} \\
(\mathrm{mmol} / \mathrm{L})\end{array}$ & $\begin{array}{c}\text { Acyl-CoA } \\
\text { dehydrogenase }\end{array}$ & $\begin{array}{l}\text { Enoyl-CoA } \\
\text { hydratase }\end{array}$ & $\begin{array}{l}\text { L-3-Hydroxyacyl-CoA } \\
\text { dehydrogenase }\end{array}$ & Thiolase & Thioesterase \\
\hline 0 & $9.302 \pm 2.270^{\mathrm{b}}$ & $\mathrm{ND}^{1}$ & $119.373 \pm 7.335^{\mathrm{b}}$ & $3.540 \pm 0.955^{c}$ & $16.176 \pm 0.318^{\mathrm{a}}$ \\
\hline 4 & $9.418 \pm 1.047^{\mathrm{b}}$ & ND & $149.116 \pm 17.067^{\mathrm{ab}}$ & $46.667 \pm 31.290^{\mathrm{b}}$ & $11.765 \pm 1.148^{\mathrm{ab}}$ \\
\hline 12 & $3.023 \pm 1.066^{\mathrm{c}}$ & $41.418 \pm 11.633^{\mathrm{a}}$ & $163.987 \pm 9.571^{\mathrm{a}}$ & $78.958 \pm 9.382^{\mathrm{a}}$ & $15.625 \pm 4.457^{\mathrm{a}}$ \\
\hline 16 & $16.511 \pm 1.846^{\mathrm{a}}$ & $82.836 \pm 58.209^{\mathrm{a}}$ & $143.087 \pm 10.040^{\mathrm{ab}}$ & $41.250 \pm 5.962^{\mathrm{b}}$ & $7.353 \pm 1.773^{\mathrm{c}}$ \\
\hline 20 & $12.558 \pm 2.287^{\mathrm{ab}}$ & $18.657 \pm 9.117^{\mathrm{a}}$ & $48.633 \pm 18.458^{\mathrm{c}}$ & $2.500 \pm 1.250^{\mathrm{c}}$ & $7.721 \pm 0.955^{\mathrm{c}}$ \\
\hline
\end{tabular}

${ }^{\mathrm{a}-\mathrm{C}}$ Values with different superscripts in the same column differ significantly $(P<0.05)$.

${ }^{1}$ Enzyme activity was not detected. 
Table 2. Influence of $\mathrm{Ca}^{2+}$ concentration on enzyme activity ( $\mathrm{nmol} / \mathrm{min}$ per $\mathrm{mg}$ of protein)

\begin{tabular}{|c|c|c|c|c|c|}
\hline $\begin{array}{l}\mathrm{Ca}^{2} \\
(\mathrm{mmol} / \mathrm{L})\end{array}$ & $\begin{array}{c}\text { Acyl-CoA } \\
\text { dehydrogenase }\end{array}$ & $\begin{array}{l}\text { Enoyl-CoA } \\
\text { hydratase }\end{array}$ & $\begin{array}{l}\text { L-3-Hydroxyacyl-CoA } \\
\text { dehydrogenase }\end{array}$ & Thiolase & Thioesterase \\
\hline 0 & $10.814 \pm 3.540^{\mathrm{b}}$ & $\mathrm{ND}^{1}$ & $119.373 \pm 7.335^{\mathrm{a}}$ & $3.540 \pm 0.955^{\mathrm{b}}$ & $16.176 \pm 0.318^{\mathrm{b}}$ \\
\hline 2 & $45.349 \pm 9.820^{\mathrm{a}}$ & $316.418 \pm 164.554^{\mathrm{ab}}$ & $96.865 \pm 20.225^{\mathrm{ab}}$ & $21.667 \pm 2.366^{\mathrm{a}}$ & $19.301 \pm 1.102^{\mathrm{a}}$ \\
\hline 6 & $62.209 \pm 19.114^{\mathrm{a}}$ & $85.597 \pm 43.914^{\mathrm{b}}$ & $83.601 \pm 5.569^{\mathrm{bc}}$ & $7.500 \pm 5.340^{\mathrm{b}}$ & $10.294 \pm 1.773^{\mathrm{c}}$ \\
\hline 8 & $41.512 \pm 16.878^{\mathrm{a}}$ & $382.024 \pm 54.053^{\mathrm{a}}$ & $123.794 \pm 15.504^{\mathrm{a}}$ & $6.667 \pm 0.361^{\mathrm{b}}$ & $3.309 \pm 0.637^{\mathrm{e}}$ \\
\hline 10 & $72.326 \pm 10.844^{\mathrm{a}}$ & $469.245 \pm 123.94^{\mathrm{a}}$ & $62.701 \pm 6.265^{\mathrm{c}}$ & $4.167 \pm 1.573^{\mathrm{b}}$ & $4.044 \pm 0.550^{\mathrm{de}}$ \\
\hline
\end{tabular}

${ }^{a-e}$ Values with different superscripts in the same column differ significantly $(P<0.05)$.

${ }^{1}$ Enzyme activity was not detected.

activity in this study was in common with other thioesterases: $\mathrm{Ca}^{2+}$ had a stimulatory effect on short-chain thioesterase activity in brown adipose tissue mitochondria at $2.5 \mathrm{mmol} / \mathrm{L}$ (Alexson and Nedergaard, 1988). Long-chain fatty acyl-CoA thioesterase activity was stimulated at low concentrations and inhibited at high concentrations of $\mathrm{Ca}^{2+}$ (Berge and Døssland, 1979).

\section{Influence of $\mathrm{Fe}^{2+}$ on Enzyme Activity}

The effects of $\mathrm{Fe}^{2+}$ ions on $\beta$-oxidation enzymes of L. lactis are shown in Table 3 , where $1 \mathrm{mmol} / \mathrm{L} \mathrm{Fe}^{2+}$ inhibited acyl-CoA dehydrogenase activity. When the concentration of $\mathrm{Fe}^{2+}$ increased to $5 \mathrm{mmol} / \mathrm{L}, \mathrm{Fe}^{2+}$ induced activities of enoyl-CoA hydratase and thiolase but inhibited activities of L-3-hydroxyacyl-CoA dehydrogenase and thioesterase. Moreover, $\mathrm{Fe}^{2+}$ had an inhibitory effect on thioesterase activity, which was not consistent with a previous report (Lee and Schulz, 1979).

\section{Influence of $\mathrm{Cu}^{2+}$ on Enzyme Activity}

The influence of $\mathrm{Cu}^{2+}$ on enzyme activity is shown in Table 4. Copper ion induced enoyl-CoA hydratase activity and inhibited activities of L-3-hydroxyacylCoA dehydrogenase and thioesterase. This result was not inconsistent with previous reports, in which $\mathrm{Cu}^{2+}$ significantly inhibited thioesterase at 1 and $1.2 \mathrm{mmol} / \mathrm{L}$ (Berge and Døssland, 1979; Lee and Schulz, 1979).

To our knowledge, there are no published studies reporting the effect of metal ions on the $\beta$-oxidation system and thioesterase activity of L. lactis. In this study, we investigated the influence of some divalent cations on 5 enzymes of incomplete $\beta$-oxidation of $L$. lactis. The activity of acyl-CoA dehydrogenase could be induced by $\mathrm{Ca}^{2+}(0-10 \mathrm{mmol} / \mathrm{L})$ and $\mathrm{Mg}^{2+}(0-20$ $\mathrm{mmol} / \mathrm{L}$ ) and separately inhibited by $1 \mathrm{mmol} / \mathrm{L} \mathrm{Fe}^{2+}$ or $12 \mathrm{mmol} / \mathrm{L} \mathrm{Mg}^{2+}$. Four of the metal divalent ions in this experiment induced activity of enoyl-CoA hydratase, and 4 inhibited L-3-hydroxyacyl-CoA dehydrogenase activity; $\mathrm{Mg}^{2+}$ strongly stimulated activity of L-3-hydroxyacyl-CoA dehydrogenase at $12 \mathrm{mmol} / \mathrm{L}$. All metal ions induced activity of thiolase but its activity decreased significantly when $0.05 \mathrm{mmol} / \mathrm{L} \mathrm{Cu}^{2+}$ was added to M17. Four ions inhibited activity of thioesterase in this study but activity decreased significantly with $\mathrm{Ca}^{2+}$ at $2 \mathrm{mmol} / \mathrm{L}$. From these data, we can conclude that activity levels of the enzymes of $\beta$-oxidation of L. lactis are induced by metal ions. Weeks et al. (1969) reported that carbon sources (palmitate or oleate) could affect enzyme activities of $\beta$-oxidation of Escherichia coli. Culture conditions could affect the activity of $\beta$-oxidation and thioesterases of bacteria.

\section{CONCLUSIONS}

We investigated the effects of divalent metal ions $\left(\mathrm{Ca}^{2+}, \mathrm{Mg}^{2+}, \mathrm{Fe}^{2+}\right.$, and $\left.\mathrm{Cu}^{2+}\right)$ on the growth, $\beta$-oxidation system, and thioesterase activity of L. lactis. Different ions significantly influenced the growth of L. lactis and significantly affected activity of the 4 key enzymes of the $\beta$-oxidation system (acyl-CoA dehydrogenase,

Table 3. Influence of $\mathrm{Fe}^{2+}$ concentration on enzyme activity (nmol/min per mg of protein)

\begin{tabular}{|c|c|c|c|c|c|}
\hline $\begin{array}{l}\mathrm{Fe}^{2+} \\
(\mathrm{mmol} / \mathrm{L})\end{array}$ & $\begin{array}{c}\text { Acyl-CoA } \\
\text { dehydrogenase }\end{array}$ & $\begin{array}{l}\text { Enoyl-CoA } \\
\text { hydratase }\end{array}$ & $\begin{array}{l}\text { L-3-Hydroxyacyl-CoA } \\
\text { dehydrogenase }\end{array}$ & Thiolase & Thioesterase \\
\hline 0 & $10.814 \pm 3.540$ & $\mathrm{ND}^{1}$ & $119.373 \pm 7.335^{\mathrm{a}}$ & $3.540 \pm 0.955^{\mathrm{c}}$ & $16.176 \pm 0.318^{\mathrm{a}}$ \\
\hline 1 & $4.651 \pm 4.132$ & $126.493 \pm 115.461^{\mathrm{b}}$ & $52.251 \pm 1.842^{\mathrm{b}}$ & $15.000 \pm 3.802^{\mathrm{bc}}$ & $7.537 \pm 2.296^{\mathrm{bc}}$ \\
\hline 3 & ND & $285.448 \pm 63.835^{\mathrm{ab}}$ & $65.916 \pm 8.723^{\mathrm{b}}$ & $51.042 \pm 3.442^{\mathrm{a}}$ & $5.515 \pm 0.955^{\mathrm{c}}$ \\
\hline 4 & ND & $103.731 \pm 28.787^{\mathrm{b}}$ & $78.376 \pm 18.796^{\mathrm{b}}$ & $25.833 \pm 14.662^{\mathrm{b}}$ & $8.640 \pm 2.088^{\mathrm{b}}$ \\
\hline 5 & ND & $521.268 \pm 294.24^{\mathrm{a}}$ & $114.148 \pm 18.537^{\mathrm{a}}$ & $27.708 \pm 1.443^{\mathrm{b}}$ & $6.801 \pm 1.773^{\mathrm{bc}}$ \\
\hline
\end{tabular}

${ }^{a-c}$ Values with different superscripts in the same column differ significantly $(P<0.05)$.

${ }^{1}$ Enzyme activity was not detected. 
Table 4. Influence of $\mathrm{Cu}^{2+}$ concentration on enzyme activity ( $\mathrm{nmol} / \mathrm{min}$ per $\mathrm{mg}$ of protein)

\begin{tabular}{lccccc}
\hline $\begin{array}{l}\mathrm{Cu}^{2+} \\
(\mathrm{mmol} / \mathrm{L})\end{array}$ & $\begin{array}{c}\text { Acyl-CoA } \\
\text { dehydrogenase }\end{array}$ & $\begin{array}{c}\text { Enoyl-CoA } \\
\text { hydratase }\end{array}$ & $\begin{array}{c}\text { L-3-Hydroxyacyl-CoA } \\
\text { dehydrogenase }\end{array}$ & Thiolase \\
\hline 0 & $10.814 \pm 3.540$ & $\mathrm{ND}^{1}$ & $119.373 \pm 7.335^{\mathrm{a}}$ & $3.540 \pm 0.955^{\mathrm{b}}$ & $16.176 \pm 0.318^{\mathrm{a}}$ \\
0.025 & $\mathrm{ND}$ & $30.970 \pm 9.651^{\mathrm{a}}$ & $50.643 \pm 2.088^{\mathrm{c}}$ & $8.958 \pm 0.361^{\mathrm{a}}$ & $10.110 \pm 3.588^{\mathrm{b}}$ \\
0.05 & $\mathrm{ND}$ & $73.507 \pm 13.996^{\mathrm{a}}$ & $73.553 \pm 0^{\mathrm{b}}$ & $1.458 \pm 0.955^{\mathrm{c}}$ & $5.699 \pm 1.148^{\mathrm{c}}$ \\
0.075 & $\mathrm{ND}$ & $74.254 \pm 9.520^{\mathrm{a}}$ & $68.730 \pm 8.354^{\mathrm{b}}$ & ND & $6.066 \pm 2.866^{\mathrm{c}}$ \\
0.1 & $\mathrm{ND}$ & $101.866 \pm 124.606^{\mathrm{a}}$ & $44.614 \pm 3.190^{\mathrm{c}}$ & ND & $5.882 \pm 1.148^{\mathrm{c}}$ \\
0.125 & $\mathrm{ND}$ & $59.701 \pm 6.165^{\mathrm{a}}$ & $44.614 \pm 2.412^{\mathrm{c}}$ & ND & $8.272 \pm 0.551^{\mathrm{bc}}$ \\
\hline
\end{tabular}

${ }^{\mathrm{a}-\mathrm{c}}$ Values with different superscripts in the same column differ significantly $(P<0.05)$.

${ }^{1}$ Enzyme activity was not detected.

enoyl-CoA hydratase, L-3-hydroxyacyl CoA dehydrogenase, and thiolase) and thioesterase in L. lactis. Because divalent metal ions have some important effects on enzyme activity, we could control the metabolic pathways through the regulation of metal ion concentrations and ultimately regulate the outputs and varieties of methyl ketones.

\section{REFERENCES}

Alegría, A., S. Delgado, C. Roces, B. López, and B. Mayo. 2010. Bacteriocins produced by wild Lactococcus lactis strains isolated from traditional, starter-free cheeses made of raw milk. Int. J. Food Microbiol. 143:61-66.

Alexson, S. E. H., and J. Nedergaard. 1988. A novel type of short- and medium-chain acyl-CoA hydrolases in brown adipose tissue mitochondria. J. Biol. Chem. 263:13564-13571.

Baltazar, M. F., F. M. Dickinson, and C. Ratledge. 1999. Oxidation of medium-chain acyl-CoA esters by extracts of Aspergillus niger: Enzymology and characterization of intermediates by HPLC. Microbiology 145:271-278.

Bellengier, P., J. Richard, and C. Foucaud. 1997. Associative growth of Lactococcus lactis and Leuconostoc mesenteroides strains in milk. J. Dairy Sci. 80:1520-1527.

Berge, R. K., and B. Døssland. 1979. Differences between microsomal and mitochondrial-matrix palmitoyl-coenzyme A hydrolase, and palmitoyl-L-carnitine hydrolase from rat liver. Biochem. J. 181:119-125.

Binstock, J. F., and H. Schulz. 1981. Fatty acid oxidation complex from Escherichia coli. Methods Enzymol. 71:403-411.

Boyaval, P. 1989. Lactic acid bacteria and metal ions. Lait 69:87-113.

Bruyneel, B., V. D. Woestyne, and M. Verstraete. 1989. Lactic and bacteria: Micro-organisms able to grow in the absence of available iron and copper. Biotechnol. Lett. 11:401-406.

Dunning, J. C., Y. Ma, and R. E. Marquis. 1998. Anaerobic killing of oral streptococci by reduced, transition metal cations. Appl. Environ. Microbiol. 64:27-33.

Eades, C. H. E., Jr., and M. Womack. 1953. Calcium as a growth stimulant for Lactobacillus casei. J. Bacteriol. 65:322-325.

Efstathiou, J. D., and L. L. McKay. 1977. Inorganic salts resistance associated with a lactose fermenting plasmid in Streptococcus lactis. J. Bacteriol. 130:257-265.

Elli, M., R. Zink, A. Rytz, R. Reniero, and L. Morelli. 2000. Iron requirement of Lactobacillus spp. in completely chemically defined growth media. J. Appl. Microbiol. 88:695-703.

Ellwood, D. C., and D. W. Tempest. 1972. Effects of environment on bacterial wall content and composition. Adv. Microb. Physiol. $7: 83-117$.

Engelvin, G., G. Feron, C. Perrin, D. Molle, and R. Talon. 2000. Identification of beta-oxidation and thioesterase activities in Staphylococcus carnosus 833 strain. FEMS Microbiol. Lett. 190:115-120.
Feron, G., C. Blin-Perrin, I. Krasniewski, G. v. Mauvais, and J. Lherminier. 2005. Metabolism of fatty acid in yeast: Characterisation of $\beta$-oxidation and ultrastructural changes in the genus Sporidiobo$l u$ ssp. cultivated on ricinoleic acid methyl ester. FEMS Microbiol. Lett. 250:63-69.

Glusker, J. P., A. K. Katz, and C. W. Bock. 1999. Metal ions in biological systems. Rigaku J. 16:8-17.

Hannon, J. A., K. N. Kilcawley, M. G. Wilkinson, C. M. Delahunty, and T. P. Beresford. 2007. Flavour precursor development in Cheddar cheese due to lactococcal starters and the presence and lysis of Lactobacillus helveticus. Int. Dairy J. 17:316-327.

Hellyer, A., P. F. Leadlay, and A. R. Slabas. 1992. Induction, purification and characterisation of acyl-ACP thioesterase from developing seeds of oil seed rape (Brassica napus). Plant Mol. Biol. 20:763-780.

Hunt, M. C., and S. E. H. Alexson. 2002. The role acyl-CoA thioesterases play in mediating intracellular lipid metabolism. Prog. Lipid Res. 41:99-130.

Imbert, M. N., and R. Blondeau. 1998. On the iron requirement of lactobacilli grown in chemically defined medium. Curr. Microbiol. 37:64-66.

Kurtz, D. M., R. J. Tolwani, and P. A. Wood. 1998. Structural characterization of the mouse long-chain acyl-CoA dehydrogenase gene and $5^{\prime}$ regulatory region. Mamm. Genome 9:361-365.

Laemmli, U. K. 1970. Cleavage of structural proteins during the assembly of the head of bacteriophage T4. Nature 227:680-685.

Lee, K. Y., and H. Schulz. 1979. Isolation, properties, and regulation of a mitochondrial acyl coenzyme A thioesterase from pig heart. J. Biol. Chem. 254:4516-4523.

Lew, L. C., M. T. Liong, and C. Y. Gan. 2013. Growth optimization of Lactobacillus rhamnosus FTDC 8313 and the production of putative dermal bioactives in the presence of manganese and magnesium ions. J. Appl. Microbiol. 114:526-535.

Li, L., and Y. Ma. 2013. Effect of fatty acids on the $\beta$-oxidation system and thioesterase of Lactococcus lactis subspecies lactis. J. Dairy Sci. 96:2003-2010.

Liu, T., S.-J. Liu, Y. Xue, Y. Ma, and P. Zhou. 2002. Purification and characterization of an extremely halophilic acetoacetyl-CoA thiolase from a newly isolated Halobacterium strain ZP-6. Extremophiles 6:97-102.

Loubiere, P., M. Cocaign-Bousquet, J. Matos, G. Goma, and N. D. Lindley. 1997. Influence of end-products inhibition and nutrient limitations on the growth of Lactococcus lactis ssp. lactis. J. Appl. Microbiol. 82:95-100.

Maggio-Hall, L. A., P. Lyne, J. A. Wolff, and N. P. Keller. 2008. A single acyl-CoA dehydrogenase is required for catabolism of isoleucine, valine and short-chain fatty acids in Aspergillus nidulans. Fungal Genet. Biol. 45:180-189.

Maher, A. C., A.-W. Mohsen, J. Vockley, and M. A. Tarnopolsky. 2010. Low expression of long-chain acyl-CoA dehydrogenase in human skeletal muscle. Mol. Genet. Metab. 100:163-167.

Mannaerts, G. P., P. P. V. Veldhoven, and M. Casteels. 2000. Peroxisomal lipid degradation via $\beta$ - and $\alpha$-oxidation in mammals. Cell Biochem. Biophys. 32:73-87. 
Mrvčić, J., A. Butorac, E. Šolić, D. Stanzer, V. Bačun-Družina, M. Cindrić, and V. Stehlik-Tomas. 2013. Characterization of Lactobacillus brevis L62 strain, highly tolerant to copper ions. World J. Microbiol. Biotechnol. 29:75-85.

Mrvčić, J., D. Stanzer, E. Šolić, and V. Stehlik-Tomas. 2012. Interaction of lactic acid bacteria with metal ions: Opportunities for improving food safety and quality. World J. Microbiol. Biotechnol. $28: 2771-2782$

Papagianni, M., N. Avramidis, and G. Filiousis. 2007. Investigating the relationship between the specific glucose uptake rate and nisin production in aerobic batch and fed-batch glucostat cultures of Lactococcus lactis. Enzyme Microb. Technol. 40:1557-1563.

Rodríguez, L. M., and T. Alatossava. 2008. Effects of copper supplement on growth and viability of strains used as starters and adjunct cultures for Emmental cheese manufacture. J. Appl. Microbiol. 105:1098-1106.

Terzaghi, B. E., and W. E. Sandine. 1975. Improved medium for lactic streptococci and their bacteriophages. Appl. Microbiol. 29:807813
Trevors, J. T., and C. M. Cotter. 1990. Copper toxicity and uptake in microorganisms. J. Ind. Microbiol. 6:77-84.

Weeks, G., M. Shapiro, R. Burns, and S. J. Wakil. 1969. Control of fatty acid metabolism. J. Bacteriol. 97:827-836.

Wright, C. T., and T. R. Klaenhammer. 1983. Influence of calcium and manganese on dechaining of Lactobacillus bulgaricus. Appl. Environ. Microbiol. 46:785-792.

Yokota, S., and T. Hashimoto. 1984. Inner membrane association of three mitochondrial beta-oxidation enzymes revealed by immunoelectron microscopic technique. Histochemistry 80:547-552.

Zeng, J., G. Deng, W. Yu, and D. Li. 2006. Inactivation of mediumchain acyl-CoA dehydrogenase by oct-4-en-2-ynoyl-CoA. Bioorg. Med. Chem. Lett. 16:1445-1448.

Zeng, J., and D. Li. 2004. Expression and purification of His-tagged rat mitochondrial 3-ketoacyl-CoA thiolase wild-type and His352 mutant proteins. Protein Expr. Purif. 35:320-326. 